\title{
In Vitro Neuroprotective Activities of Natural Products Isolated from Senecio Graciliflorus $D C$ against Corticosterone Induced Impairment in SH- SY5Y Cells
}

\section{Salman Jameel \\ Indian Institute of Integrative Medicine \\ Loveleena kaur \\ Indian Institute of Integrative Medicine \\ Showkat Ahmad Bhat \\ Indian Institute of Integrative Medicine}

Fayaz A Malik

Indian Institute of Integrative Medicine

KHURSHEED Ahmad BHAT ( $\square$ kabhat@iiim.ac.in )

Indian Institute of Integrative Medicine https://orcid.org/0000-0001-5489-6314

\section{Research Article}

Keywords: Senecio, Sterol, Sarcinnic acid, Neuroprotection, Corticosterone

Posted Date: June 16th, 2021

DOl: https://doi.org/10.21203/rs.3.rs-582672/v1

License: (c) (i) This work is licensed under a Creative Commons Attribution 4.0 International License.

Read Full License

Version of Record: A version of this preprint was published at Naunyn-Schmiedeberg's Archives of Pharmacology on September 23rd, 2021. See the published version at https://doi.org/10.1007/s00210021-02136-9. 


\section{Abstract}

Senecio graciliflorus DC root extract was studied for secondary metabolite composition following bioactivity guided isolation technique. The ethyl acetate extract of Senecio graciliflorus root yielded nine chemical constituents: 3,4-di-tert-butyl toluene, stigmasterol, $\beta$-sitosterol, $2 \beta$ (angeloyloxy)furanoeremophilane, gallic acid, $2 \beta-\{[(Z)-2$-hydroxymethylbut-2enoyl]oxy\}furanoeremophilane,1-Hydroxypentan-2-yl-4-methylbenzoate, sarcinnic acid, and sitosterol 3-0$\beta$-D-glucopyranoside. The structures of the chemical constituents were elucidated on the basis of spectral data analysis in the light of literature. All the compounds are being reported for the first time from this plant. The isolated constituents were screened for in-vitro neuroprotective effects against corticostereone induced impairment. Among various isolated compounds, three natural products (sarcinnic acid, gallic acid and $\beta$-sitosterol) displayed robust neurotropic activity. These three compounds increased neuronal cell survival in differentiated neuroblastoma cells from high dose corticosterone $(400 \mu \mathrm{M})$ induced cell death. The studies are aimed to explore small molecules for treating neurodegeneration underlying various neurological disorders to restore neuronal cell plasticity.

\section{Introduction}

Senecio (tribe Senecioneae), is the largest genus of family Asteraceae (Compositae) consisting of more than 1500 species with worldwide distribution. The genus has been extensively studied for secondary metabolite composition [1]. Pyrrolizidine alkaloids (PAs), eremophilanolides, and cacalolides are the characteristic classes of compounds contained in the genus [2]. Senecio species not only enjoy positive impact but also cherish a negative impact in many agricultural countries, because such plants cause deaths to livestock than any other poisonous plant. Their toxicity concerns are mainly attributed to their content of pyrrolizidine alkaloids and some furanoeremophilanes [3]. Senecio species were used in the folk medicine for the treatment of wounds, antiemetic, anti-inflammatory, and vasodilatory preparations [1]. Phytochemistry of a number of Senecio species have resulted into the identification of diverse class of constituents which include pyrrolizidines, eremophilanes, flavonoids, diterpenes, triterpenes, sesquiterpenes [4-9]. Among the naturally occurring N-containing compounds, the PAs of macrocyclic senecionine type constitute an important group. These compounds are pharmacologically potent and characteristic secondary metabolites for most species of the genus Senecio which cause hepatotoxicity to animals [10]. Senecio species possess antibacterial and antifungal activities [1]. A thorough biological study of the genus Senecio has revealed that the extracts as well as compounds of the genus possess hepatotoxic, teratogenic or carcinogenic effects, antifeedant activity, anti-mitotic effect, and inhibition of angiotensinogen converting enzyme (ACE), insecticidal and neurotoxic activity [11-16].

Senecio graciliflorus DC grows in the alpine forests and meadows of Kashmir valley. It is locally known as "Bhagghu". The water extract of the leaves is a folk medicine for the treatment of skin rashes and eruptions [17-18]. Earlier we have reported the essential oil analysis of differ parts of $S$. graciliflorus DC using GC-FID and GC-MS. The essential oil contains a-pinene, cis-ocimene, 1,2,3-trimethylcyclohexane and $\beta$-pinenes as the major constituents [19]. 
However, to the best of our knowledge, there are no reports about the secondary metabolites and neuroprotective effects of $S$. graciliflorus DC and its constituents. So, we have carried out bioactivity guided isolation of natural products from $S$. graciliflorus and investigated the isolated components for neuroprotection against corticosterone induced neurotoxicity using SH-SY5Y cells.

\section{Experimental Section}

\subsection{Plant material and chemicals}

Senecio graciliflorus DC was collected from the high altitude areas of Gulmarg region of Kashmir valley in the month of September 2017. The plant was authenticated by Prof. A. R. Naqshi (Ex. Professor) Department of Botany, University of Kashmir. Voucher specimen bearing no IIIMH-SP-1001 was deposited in the herbarium of the institute, IIIM Srinagar. Corticosterone was purchased from Sigma Aldrich. Organic solvents and silica gel (60-120) used were purchased from Merck. Media along with supplements were procured from Gibco. Natural molecules were dissolved in cell culture grade DMSO (Sigma) and stored at $-20^{\circ} \mathrm{C}$.

\subsection{Preparation of extract}

The root part of the plant was processed separately, chopped, oven dried at $40^{\circ} \mathrm{C}$ and ground to a fine powder. The powdered roots $(2.0 \mathrm{~kg})$ were extracted sequentially by maceration with ethyl-acetate. The solvent was removed under vacuo on a rotary evaporator to afford crude ethyl acetate extract of root part (80.0 g).

\subsection{Analytical techniques}

NMR spectra were obtained on $400 \mathrm{MHz}$ Bruker spectrometer in $\mathrm{CDCl}_{3}$ and $\mathrm{MeOD}$ with TMS as internal standard. Mass analysis was carried out on LC-MS 8030 mass spectrometer (Shimadzu Corporation, Kyoto, Japan). All the compounds were analysed in full scan mode with nitrogen serving as an interface gas. Column chromatography was carried on normal silica gel (60-120 mesh) (Merck grade) and precoated TLC plates with silica gel $60 \mathrm{~F}_{254}$ (Merck, $0.25 \mathrm{~mm}$ ) were used for monitoring the column chromatograph.

\subsection{SH-SY5Y cell culture}

Human neuroblastoma cell lines were propagated in DMEM-F12 media supplemented with 10\% FBS, penicillin, and streptomycin in $\mathrm{CO}_{2}$ atmosphere in humidified incubator. Cells were subjected to differentiation using retinoic acid. Cells were collected and subjected to digestion in $0.05 \%$ trypsin - EDTA solution. Experiments were performed with cell within 12-18 passages.

\subsection{Cell survival analysis}

Cells were incubated in 96 well plates $(200 \mu \mathrm{L} /$ well) with seeding density of $1 \times 10 \mathrm{Q}$ cells $/ \mathrm{ml}$. After treatment, $20 \mu \mathrm{L}$ MTT dye $(5 \mathrm{mg} / \mathrm{ml})$ was added to each well and kept for $2 \mathrm{hrs}$. Formazon crystals 
formed were dissolved in cell culture grade DMSO and the values were measured using plate reader at $570 \mathrm{~nm}$. All experiments were performed in triplicates, significance value $(P<0.01 * \star *)$.

\subsection{Corticosterone induced cell impairment model}

Cell based toxicity assay was established to induce cell impairment in cells subjected to Corticosterone $(10 \mu \mathrm{L}$ of $400 \mu \mathrm{mol} / \mathrm{L})$ treatment; cell survival was mainly dependent upon addition of certain external neurotropic factors (DHF/molecules). MTT assay was used to determine percentage cell survival after 48 hr of compound treatment.

\subsection{Statistical analysis}

Graph Pad Prism software was implied for statistical analysis followed by one way ANOVA variance. Experiments were replicated in set of triplicates and the results were assessed as mean of $\pm S D$ of three independent experiments and the significance was expressed at $\mathrm{P}<0.01$ **.

\section{Result And Discussion}

\subsection{Isolation of chemical compounds}

The constituents from S. graciliflorus were isolated following bioactivity guided isolation and purification methodology. Both the shoot and root extracts were first screened for cell viability against corticosterone induced toxicity in differentiated human neuroblastoma cell line (SH-SY5Y)

The extracts were screened for cell viability both in presence and absence of corticosterone. Contrary to shoot, the root extract showed either similar or better cell viability than control at two different

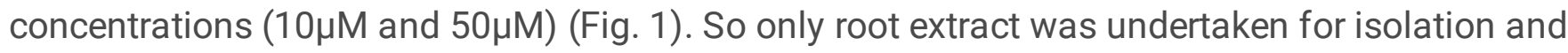
identification of active constituents. Thus $60.0 \mathrm{~g}$ of the ethyl-acetate extract of $S$. graciliflorus DC root was subjected to fractionation and purification of constituents using normal phase column chromatography.

Four fractions $\mathrm{Fr}-1, \mathrm{Fr}-2, \mathrm{Fr}-3$, and $\mathrm{Fr}-4$ of root extract were obtained using Hexane-EtOAc as eluent with increasing polarity of $10,30,50$ and $80 \%$ ethyl acetate respectively. Purification of $\mathrm{Fr}-1$ yielded two constituents $\mathrm{C}-01$ and $\mathrm{C}-02$. Similarly $\mathrm{C}-03$ and $\mathrm{C}-04 ; \mathrm{C}-05$ and $\mathrm{C}-06$ were obtained from Fr-2 and Fr-3 respectively. Repeated column chromatography of Fr-4 yielded C-07, C-08 and C-09 as pure isolates. The structures of isolated constituents were characterised based on spectral data analysis in the light of literature. Thus the isolated natural products were identified as 3,4-di-tert-butyl toluene (C-01), stigmasterol (C-02), 2 $\beta\{[(Z)-2-H y d r o x y m e t h y l b u t-2-e n o y l]$ oxy $\}$ furanoeremophilane (C-03), gallic acid (C04), $\beta$-sitosterol (C-05), $2 \beta$ (Angeloyloxy)furanoeremophilane (C-06), 1-Hydroxypentan-2-yl-4methylbenzoate (C-07), sarcinnic acid (C-08), and sitosterol 3-0- $\beta$-D-glucopyranoside (C-09) (Fig. 2) [2027]. All the compounds were isolated for the first time from $S$. graciliflorus DC.

\subsection{Natural compounds as potential pro survival entities against neural cells(SH-SY5Y)}


To search for natural molecules with potential cell survival activity, cell line based assay was employed. Among the library of compounds screened only three compounds showed significant cell survival activities from the root part of plant (Fig. 2).

\subsection{Neuroprotective activity of selected hits against corticosterone induced cell toxicity}

Human neuroblastoma cell lines were pre incubated with positive hits ( $24 \mathrm{hrs}$.), later subjected to high dose Corticosterone $(400 \mu \mathrm{M})$ treatment again for $24 \mathrm{hrs}$ (Fig. 3). Corticosterone induces impairment in differentiated cell lines showing obvious injury, reversed by the selected hits thereby increasing cell survival. Initially differentiated human neuroblastoma cell lines were incubated with root and shoots extracts in presence and absence of corticosterone for 48hrs. Though most of the constituents showed positive effects on cell viability but three constituents (C-04, C-05 and C-08) were capable of restoring cell survival (Fig. 1).

\subsection{Protective Effects of Natural products (C-04, C-05 and C-08) against corticosterone induced cytotoxicity in human neuroblastoma cell lines (SHSY5S)}

The effect of natural isolates (C-04, C-05 and C-08) on viability of Human neuroblastoma cell lines SHSY5S cells was studied in presence and absence of corticosterone. The viability of SHSY5S cells was determined using MTT assay. Human neuroblastoma cell lines were preincubated with three natural products C-04, C-05 and C-08, which showed the best cell viability in preliminary screening, for 24 hours and later subjected to corticosterone treatment for another 24 hours. As expected corticosterone treatment at $400 \mu \mathrm{M}$ concentration induced cell impairment which resulted into decreased cell viability. Similar to DHF (5nM) treatment the cell viability remained unaffected, compared to control, when the cells were treated with $\mathrm{C}-04, \mathrm{C}-05$ and $\mathrm{C}-08$ only at $20 \mu \mathrm{M}$ concentration. On the other hand the cell viability increased after the treatment of the cells with $20 \mu \mathrm{M}$ solution of C-04, C-05 or C-08 for 24 hours prior to corticosterone treatment (Fig. 3). These results clearly indicate that the isolated constituents (C-04, C-05 and C-08) from S. graciliflorus show neuroprotective effects on SHSY5S cell lines.

In another experiment SHSY5S cells were treated only with different concentrations of C-04, C-05 and C08 without the treatment of corticosterone. The treatment of SH-SY5S cells with C-04, C-05 and C-08 showed a dose dependent response. The cell viability increased up to $31.25 \mu \mathrm{M}$ concentration of all the three natural products C-04, C-05 and C-08 but decreased beyond this concentration and proved to be toxic at higher concentrations. Though lower concentrations of the positive compounds enhanced cell viability but their effects after a certain dose level provoke neuronal damage in differentiated neuroblastoma cell lines (Fig. 4).

\subsection{Screening of C-04, C-05 and C-08 for activation of various survival proteins}


All the three natural isolates $\mathrm{C}-04, \mathrm{C}-05$ and $\mathrm{C}-08$ which showed neuroprotection were screened for activation of survival proteins using differentiated neuroblastoma cells under standard optimised conditions of temperature and humidity. Earlier SHSY5Y cells were subjected to differentiation 5 days prior to incubation with compounds in concentration dependent manner for $48 \mathrm{hrs}$. Multiple line experiments were performed to study the effect of positive hits (C-04, C-05 and C-08) on neuronal cell survival and activation of various survival pathways.

Since AKT/ PI3K signalling pathway plays an important role in promoting neuronal survival, the mechanism by which $\mathbf{C}-04, \mathbf{C}-05$ and $\mathbf{C}-08$ protect SHSY $5 Y$ cells from corticosterone induced neurotoxicity was particularly explored by studying the effect of these constituents on AKT, ERK activation. We examined the phosphorylation of AKT and ERK. Though all the three isolates showed phosphorylation of AKT/ ERK but C-08 lead to maximum increase in the phosphorylation of AKT/ ERK in SHSY5Y neuroblastoma cells (Fig. 5). Thus these results clearly indicate that $\mathbf{C}-04, \mathbf{C}-05$ and $\mathbf{C}-08$ cause neuroprotection against corticosterone induced neurotoxicity by expressing AKT/ ERK pathway.

The effect of different concentrations of positive hits (C-04, C-05 and C-08) on AKT/ ERK expression was also studied and the resulted showed that all the three constituents showed maximum AKT/ ERK pathway activation at $20 \mu \mathrm{M}$ concentration compared to $10 \mu \mathrm{M}$ or $40 \mu \mathrm{M}$ (Fig. 6/Fig. 7 ).

\subsection{C-08 induces AKT, ERK activation in differentiated neuroblastoma cells in time dependent manner}

In order to study whether the neurotropic activity is time dependent, we determined the phosphorylation reaction at different time intervals after differentiating SHSY5Y cells for a period of 5 days and later incubated with $\mathrm{C}-08$ at optimum conditions of humidity and temperature. C-08 activated the survival

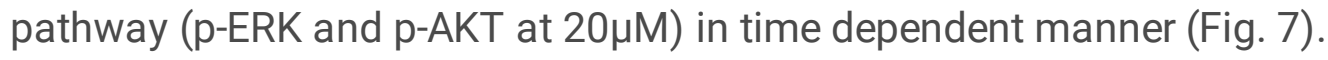

\section{Conclusion}

In conclusion S. graciliflorus DC was studied both for its secondary metabolite composition and neuroprotection. The secondary metabolite composition of the roots of $S$. graciliflorus DC yielded nine chemical constituents which were identified as 3,4-di-tert-butyl toluene, stigmasterol, $\beta$-sitosterol), gallic acid, $2 \beta$ (Angeloyloxy)furanoeremophilane, $2 \beta-\{(Z)-2-H y d r o x y m e t h y l b u t-2-$ enoyl]oxy\}furanoeremophilane, sarcinnic acid, sitosterol 3-0- $\beta$-D-glucopyranoside, and 1-Hydroxypentan2-yl-4-methylbenzoate. All the compounds are being reported for the first time from S. graciliflorus DC. The in-vitro screening of the isolated constituents for neuroprotective effects against corticosterone induced impairment resulted in the identification of three natural products (gallic acid, sarcinnic acid and $\beta$-sitosterol) with promising neuroprotective activity. All the three positive constituents enhanced cell survival /cell viability in corticosterone induced toxicity in SHS5YS cells through AKT/ ERK pathway activation in concentration and time dependent manner. 


\section{Declarations}

Acknowledgement: The authors (Showkat Ahmad Bhat and Loveleena Kaur) are thankful to CSIR and DST respectively for providing fellowship support.

Ethical approval: The work was reviewed and approved by institutional ethics and publication committee. The committee has assigned CSIR-IIIM/IPR/00291 as the research paper number.

Consent to Participate: Not applicable

Consent to Publish: All the authors agree to publish the research work.

Author contributions: Khursheed Ahmad Bhat and Fayaz A Malik conceived and designed the research work, supervised the experimental work, interpreted the experimental data, participated in writing the manuscript. Salman Jameel and Loveleena Kaur did the experimental work, participated in writing the manuscript. Showkat Ahmad Bhat contributed to the isolation of pure natural products. All authors approved the final version of the article. The authors declare that all data were generated in-house and that no paper mill was used.

Funding: The research work was partly funded by CSIR and DST by providing fellowship to Showkat Ahmad Bhat and Loveleena Kaur

Competing Interests: All authors declare no competing interest.

Availability of data and materials: The research data is available as a supplementary file

\section{References}

1. Loizzo MR, Statti GA, Tundis R, Conforti F, Bonesi M, Autelitano G, Houghton PJ, Miljkovic-Brake A, Menichini F (2004) Antibacterial and antifungal activity of Senecio inaequidens DC and Senecio vulgaris L. Phytother Res 18:777-779

2. Burgueno-Tapia E, Hernandez LR, Resendiz-Villalobos AY, Joseph-Nathan P (2004) Conformational evaluation and detailed ${ }^{1} \mathrm{H}$ and ${ }^{13} \mathrm{C}$ NMR assignments of eremophilanolides. Magn Reson Chem 42:887-892

3. Burgueno-Tapia E, Joseph-Nathan P (2003) Cacalolides from Senecio barba-johannis. Magn Reson Chem 41:386-390

4. Bohlmann F, Zdero F, Jakupovic C, Grenz J, Castro M, Kino V, Robinson RM, Vincent H LPD (1986) Further pyrrolizidine alkaloids and furanoeremophilanes from Senecio species. Phytochem 25:11511159

5. Ahmed M, Jakupovic J, Bohlmann F, Niemeyer HM (1991) Highly oxygenated furoeremophilane derivatives from Senecio zoellneri. Phytochem 30:2407-2409 
6. Tan DP, Chou GX, Wang ZT (2010) Phenolic compounds from Senecio scandens. Biochem Systemat Ecol 38:122-124

7. Cheng D-L, Cao X-P, Cheng J-K, Roeder E (1992) Diterpene glycosides from Senecio rufus. Phytochem 32:151-153

8. Rucker G, Manns D, Schenkel EP, Hartmann H, Heinzmann BM (1999) Triterpenes with a new 9-epicucurbitan skeleton from Senecio selloi. Phytochem 52:1587-1591

9. Merfort I (2002) Review of the analytical techniques for sesquiterpenes and sesquiterpene lactones. J Chromatogr A 967:115-130

10. Suau R, Cabezudo B, Rico R, Najera F, Lopez-Romero JM, Garca Al (2002) Pyrrolizidine alkaloids from three Spanish Senecio species. Biochem Syst Ecol 30:981-984

11. Dong-Liang C, Jin-Kui N, Roeder E (1992) Pyrrolizidine alkaloids from Senecio kaschkarovii. Phytochem 31:3671-3672

12. Steenkamp V, Stewart MJ, Van der Merwe S, Zuckerman M, Crowther NJ (2001) The effect of Senecio latifolius a plant used as a South African traditional medicine on a human hepatoma cell line. $\mathrm{J}$ Ethnopharmacol 78:51-58

13. Reina M, Gonzalez-Coloma A, Gutierrez C, Cabrera R, Rodriguez ML, Fajardo V, Villarroel L (2001) Defensive Chemistry of Senecio miser. J Nat Prod 64:6-11

14. Reina M, Nold M, Santana O, Orihuela JC, Gonzalez-Coloma A (2002) C-5-Substituted Antifeedant Silphinene Sesquiterpenes from Senecio palmensis. J Nat Prod 65:448-453

15. Tundis R, Loizzo MR, Statti GA, Deguin B, Amissah R, Houghton PJ, Menichini F (2005) Chemical Composition of and Inhibition of Angiotensin-Converting Enzyme by Senecio samnitumhuet. Pharm Biol 43:605-608

16. Xu H, Zhang N, Casida JE (2003) Insecticides in Chinese Medicinal Plants: Survey Leading to Jacaranone, A Neurotoxicant and Glutathione-Reactive Quinol. J Agric Food Chem 51:2544-2547

17. Koul MK (1997) Medicinal Plants of Kashmir and Ladakh, Temperate and Cold Arid Himalaya Indus Publishing Company, FS-5, Tagore Garden, New Delhi, 102

18. Joshi S, Shrestha K, Bajraacharya DM (2013) Secondary Metabolite variation in some species of Senecio L. from Nepal Himalaya. Pharmalnnov J 2:70-76

19. Lone SH, Bhat KA, Bhat HM, Majeed R, Anand R, Hamid A, Khuroo MA (2014) Essential oil composition of Senecio graciliflorus DC: Comparative analysis of different parts and evaluation of antioxidant and cytotoxic activities. Phytomed 21:919-925

20. Hambley TW, Sternhell S, Tansey CW (1990) The Synthesis and Structure of 3,4-Di-t-butylbenzoic Acid. Aust J Chem 43:807-814

21. Nayak PS, Kar DM, Nayak SP (2015) Isolation and characterization of stigmasterol from chloroform fraction of aerial part of Argemone mexicana L. Int J Pharm Sci 7:25-29

22. Bohlmann F, Ziesche J (1980) Eremophilane derivatives from Senecio species. Phytochem 19:26812684 
23. Gnawali GR, Acharya PP, Rajbhandari M (2013) Isolation of Gallic Acid and Estimation of Total Phenolic Content in Some Medicinal Plants and Their Antioxidant Activity. Nepal J Sci Technol 14:95-102

24. Awad AB, Chan KC, Downie AC, Fink CS (2000) Peanuts as a source of $\beta$-Sitosterol, a sterol with anticancer properties. Nutr Cancer 36:238-241

25. Yeon KJ, Hakjune R, Misoo K (2002) Conversion of Cyclic Acetals to Hydroxy Esters by MCPBA Oxidation. J Korean Chem Soc 46:479-483

26. Shuzo A, Kunihiko SA (1960) A branched saturated $C^{15}$ acid (sarcinnic acid) from sarcina phospholipids and a similar acid from several microbial lipids. J Biochem 47:222-229

27. Jares EA, Tettamanzi MC, Pomilio AB (1990) Sitosterol 3-O- $\beta$-d-glucuronopyranoside from Senecio bonariensis. Phytochem 29:340-341

\section{Figures}

a

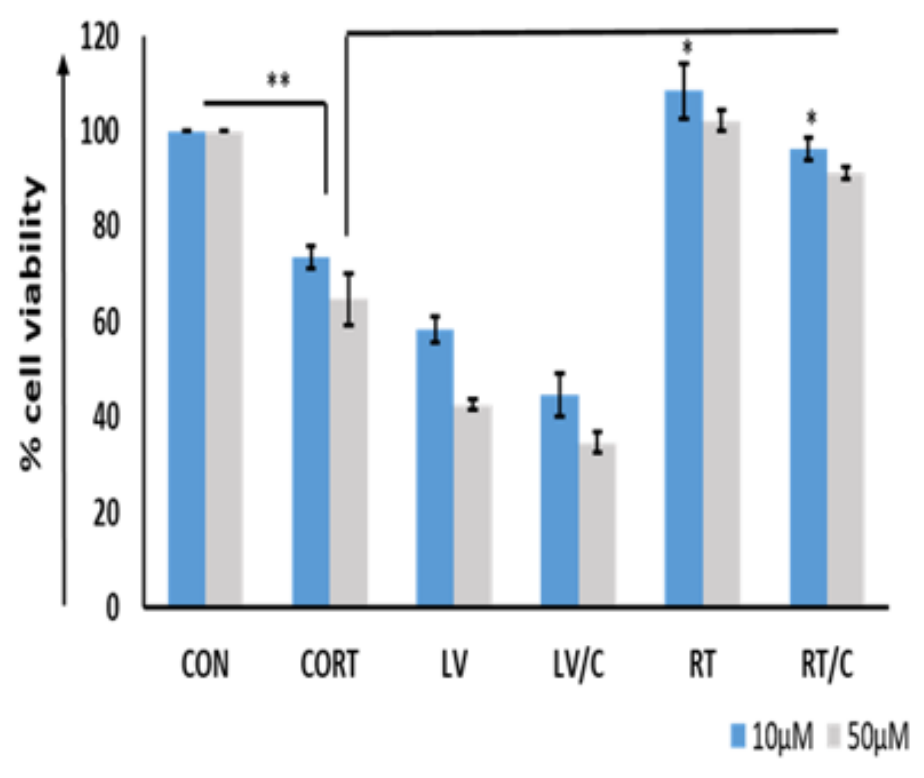

b

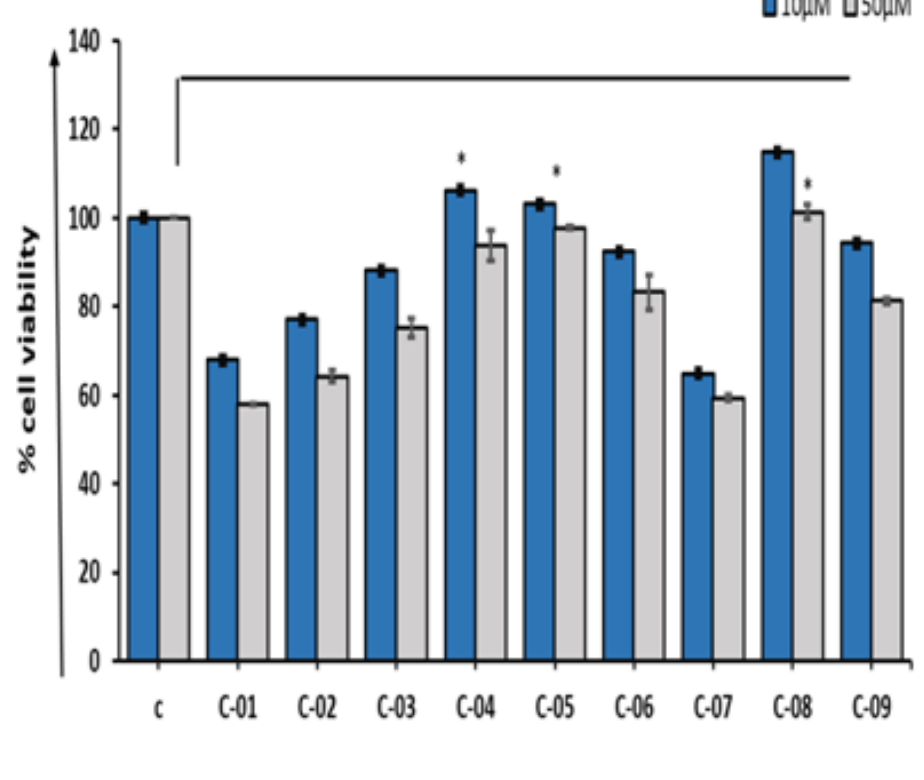

Figure 1

Screening of compounds using human neuroblastoma cell lines a) Survival analysis of differentiated human neuroblastoma cell line (SH-SY5Y) incubated with extracts in presence and absence of corticosterone: control (CON), corticosterone (CORT), leaf extract (LV), root extract (RT) b) Screening of molecules isolated from root extract for cell survival activity. 
<smiles>Cc1ccc(C(C)(C)C)c(C(C)(C)C)c1</smiles>

3, 4-di-tert-butyl toluene (C-01)<smiles>O=C(O)c1cc(O)c(O)c(O)c1</smiles>

Gallic acid (C-04)<smiles>CC[C@H](/C=C/[C@@H](C)C1CCC2C3CC=C4C[C@@H](O)CC[C@]4(C)C3CC[C@@]21C)C(C)C</smiles>

Stigmasterol (C-02)

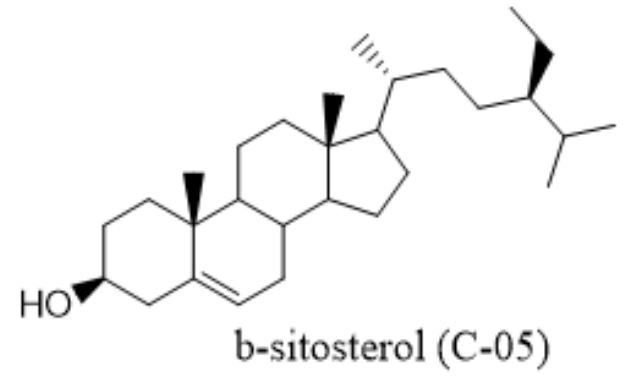<smiles>C/C=C(/CO)C(=O)O[C@H]1C[C@H](C)[C@@]2(C)Cc3occ(C)c3C[C@H]2C1</smiles>

2b-\{[(Z)-2-Hydroxymethylbut-2-enoyl $]$ oxy\}furanoeremophilane (C-03)<smiles>C/C=C(/C)C(=O)O[C@@H]1C[C@@H]2Cc3c(C)coc3C[C@@]2(C)[C@H](C)C1</smiles>

2-b-(Angeloyloxy)furanoeremophilane (C-06)<smiles>CCCC(CO)OC(=O)c1ccc(C)cc1</smiles>

1-Hydroxypentan-2-yl-4-methylbenzoate (C-07)<smiles>C/C=C(/CO)C(=O)O</smiles>

Sarcinic acid (C-08)

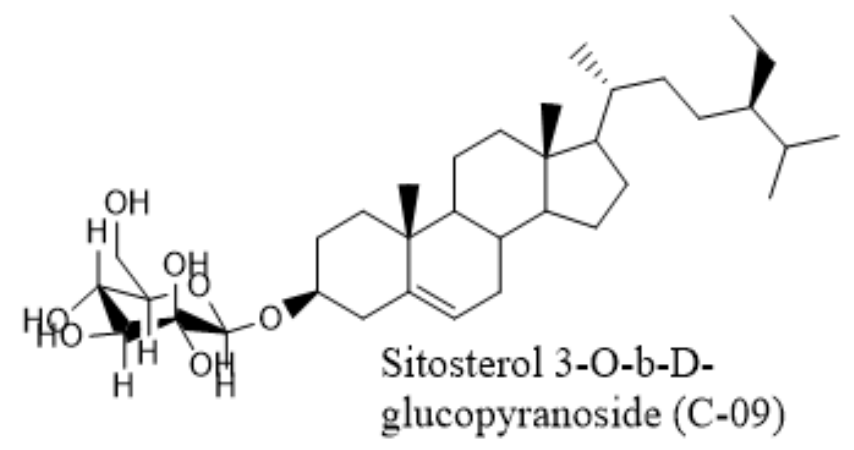

\section{Figure 2}

Structures of the isolated compounds from the roots of S. graciliflorus DC 

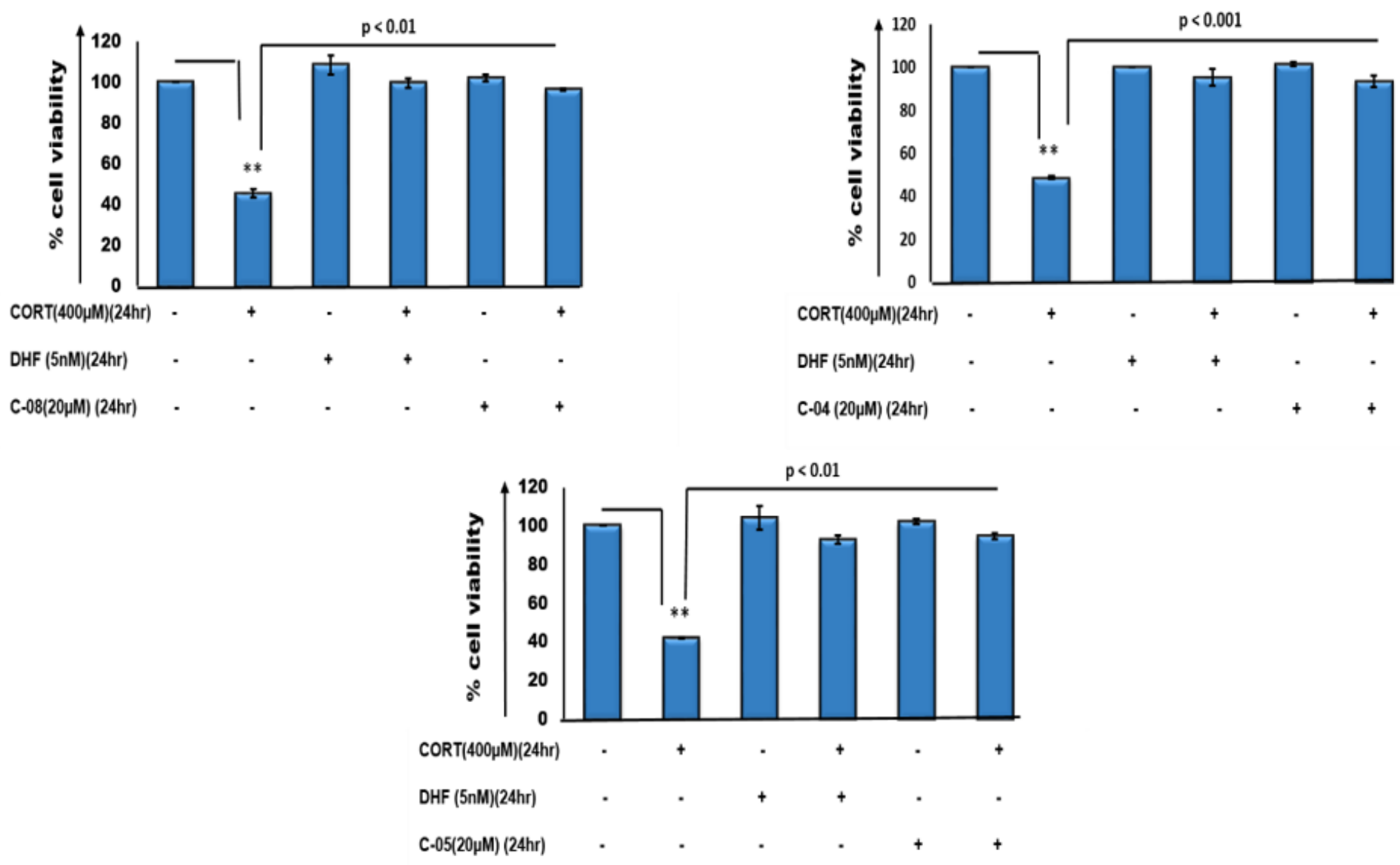

Figure 3

Protective effects of natural isolates (C-04, C-05, and C-08) on SHSY5Y cells in corticosterone induced impairment using MTT assay. Cells were subjected to corticosterone induced toxicity for $24 \mathrm{hrs}$ after preincubating with compounds. $(\mathrm{P}<0.01 * *)$ 

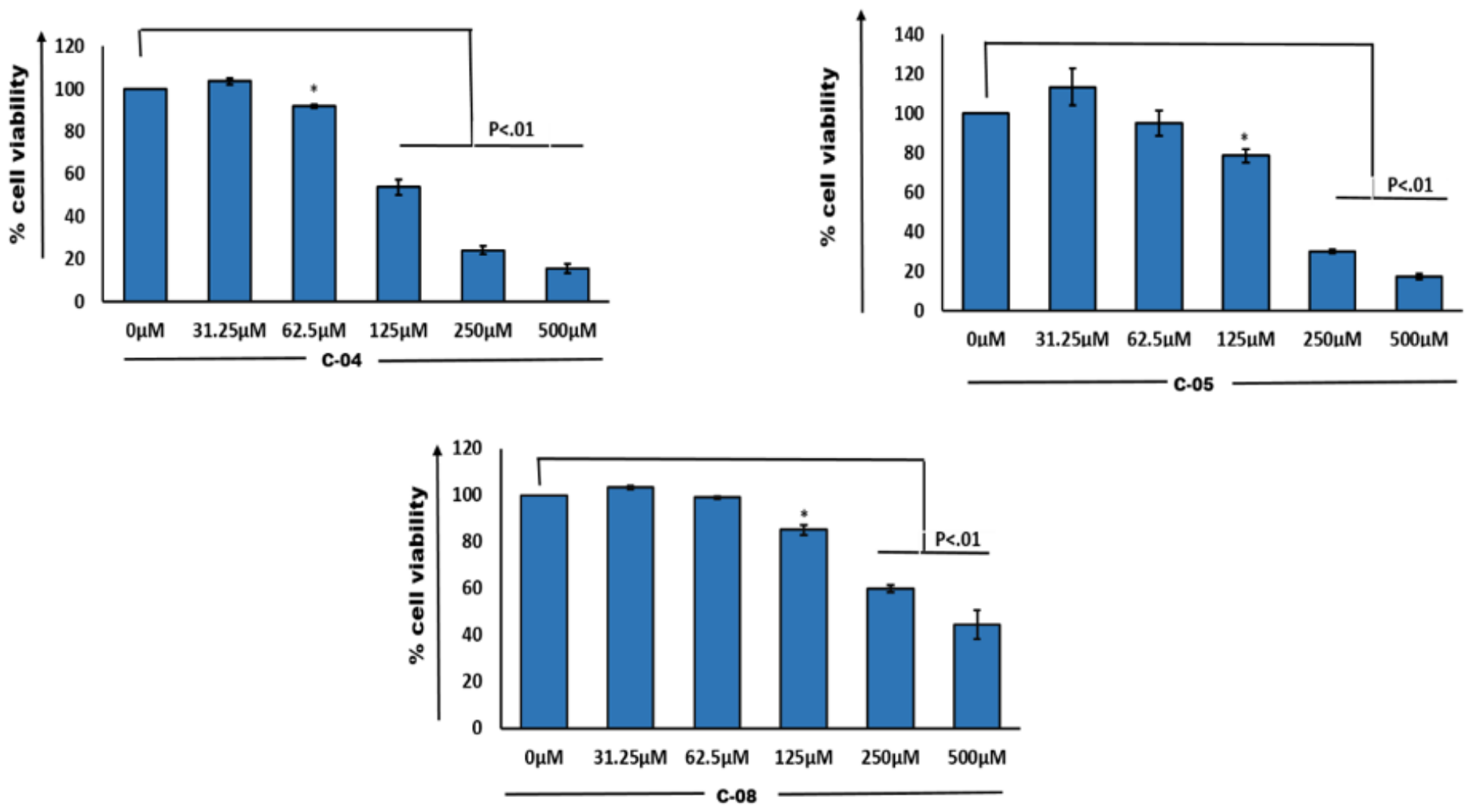

Figure 4

Cell viability after treatment of cells with increased concentration of C-04, C-05 and C-08
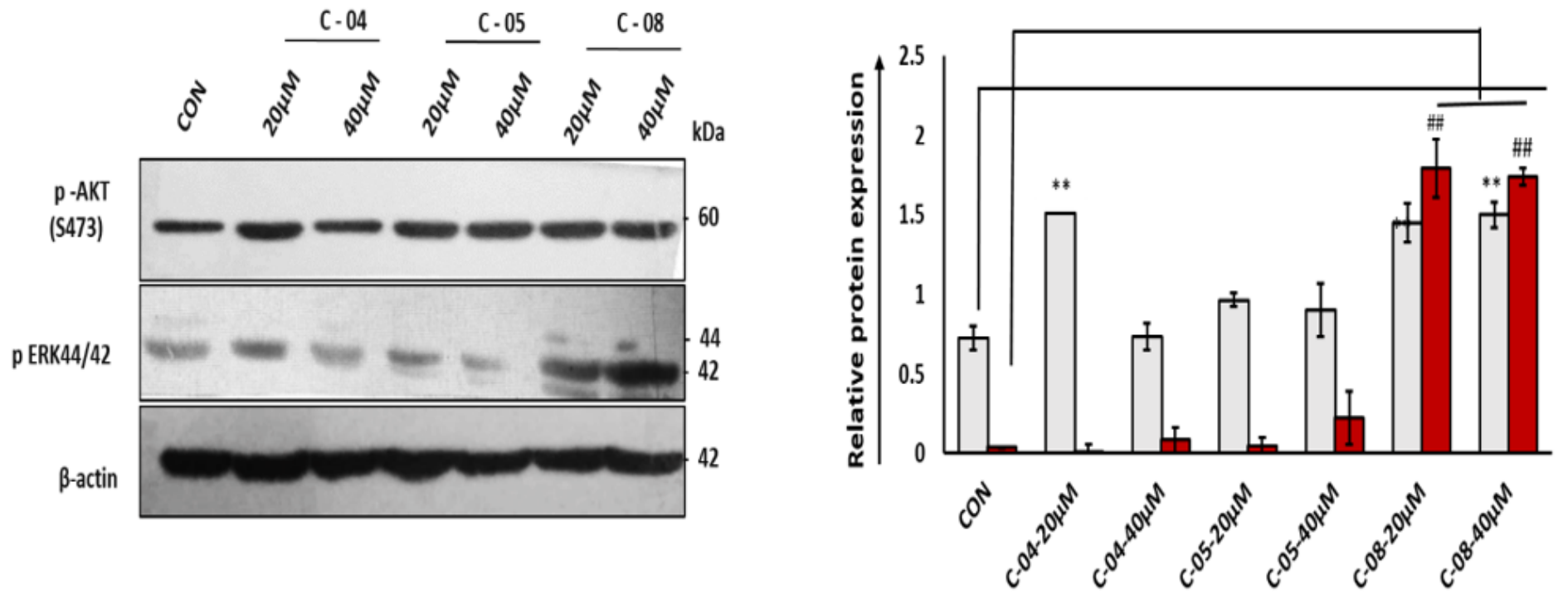

口p AKT 473 Dp ERK 44/42

Figure 5

Screening of natural molecules as potent activators of survival pathways 

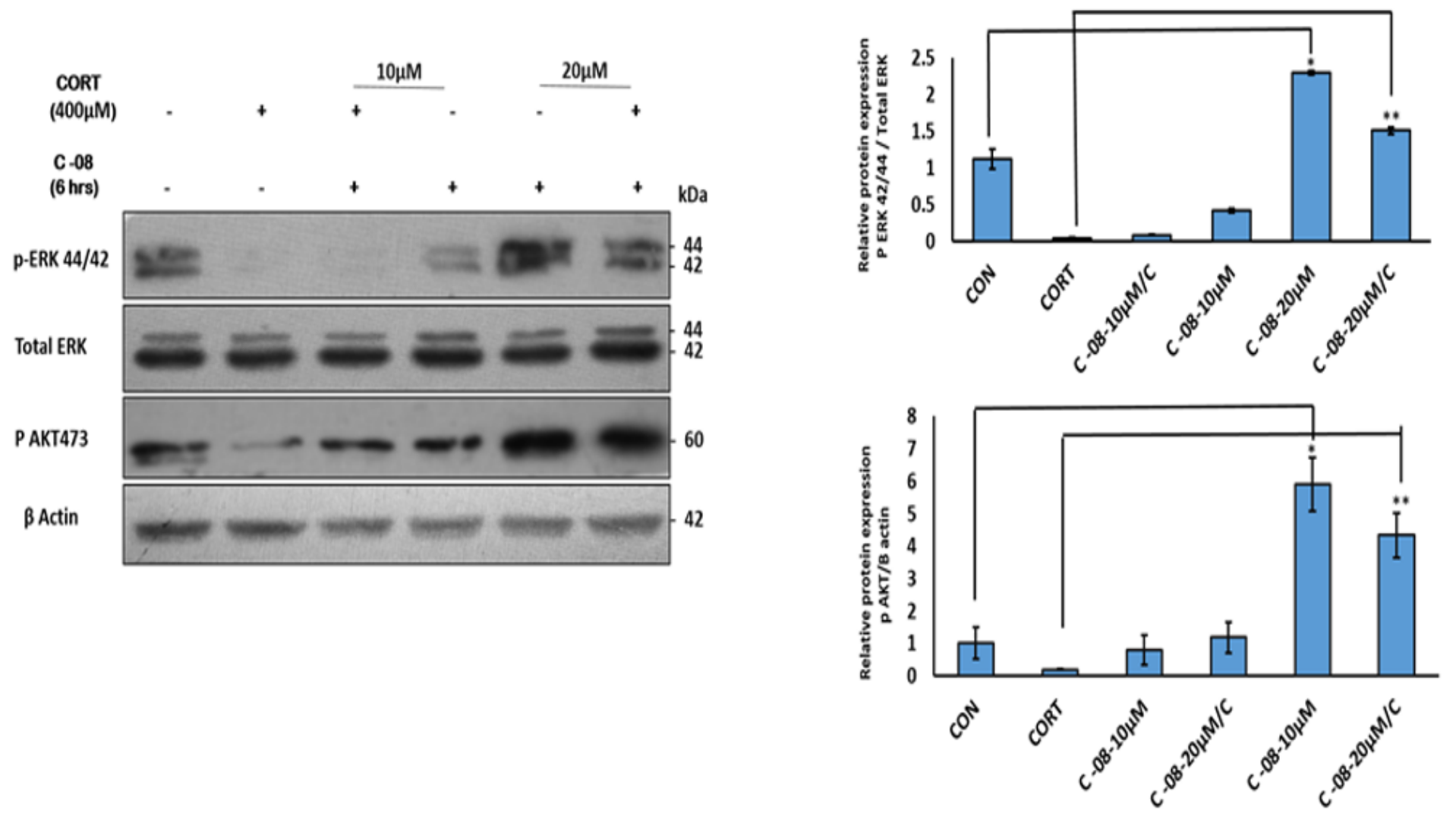

Figure 6

C-08 functions through the activation of ERK / AKT pathways: Left-C-08 incubated with differentiated SHSY5Y showing the induced expression of p-ERK44/42 along with p-AKT. Right-Quantification of survival protein were expressed at $p<0.001 * \star \star, p<0.01^{\star *}, p<0.05^{\star}$ respectively 


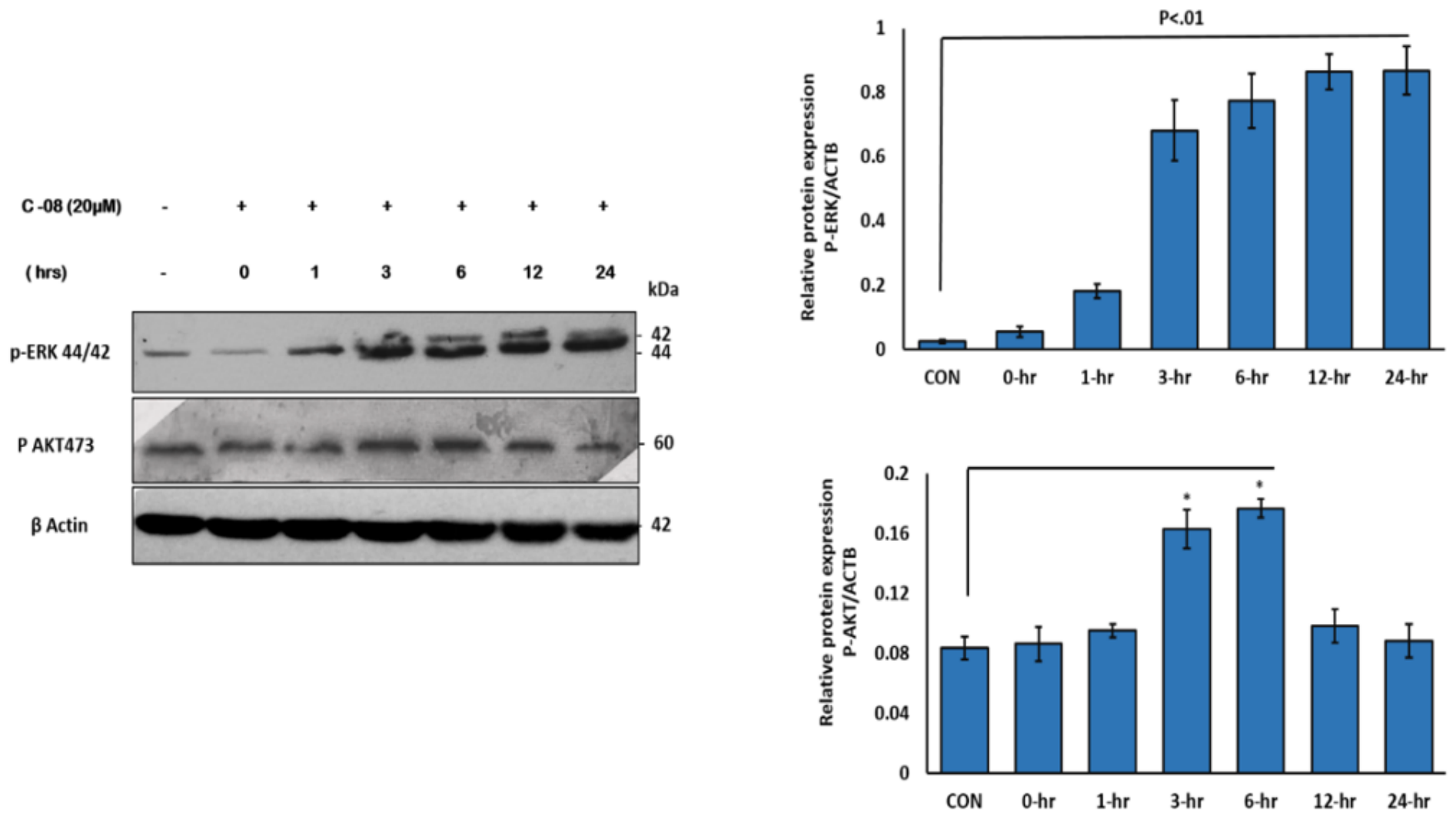

Figure 7

C-08 activates ERK / AKT pathway in time dependent manner in differentiated cells: Left-cultures treated with C-08 increases the expression of p-ERK44/42 and p-AKT within 3 hrs and reaches maximum after 6 and 12 hours in AKT and ERK pathways respectively. Right-Quantification of survival protein were expressed at $p<0.001 * \star *, p<0.01^{\star *}, p<0.05^{\star}$ respectively

\section{Supplementary Files}

This is a list of supplementary files associated with this preprint. Click to download.

- SUPPLYDATAOFSENECIO.doc

- Supplementarydata2.xlsx 